\title{
PENINGKATAN KESADARAN HUKUM SISWATENTANG BAHAYA PERBUATAN BULLY DI SMP MUHAMMADIYAH 2 PEKANBARU
}

\author{
R. Desril*, Aksar, Triwahyuni Lestari, Raihana, \\ Elviandri, Desi Somalia Agustina \\ Prodi Ilmu Hukum, Fakultas Hukum \\ Universitas Muhammadiyah Riau \\ email: rajadesril@umri.ac.id
}

\begin{abstract}
Bullying behaviour in a school environment can create a less supportive environment for students self-development, bullying behavior can hurt students, so they feel unwanted and rejected by their environment. This will certainly bring effect to the various activities of the students in the school. Causes of bullying due to family factors, environmental factor, school factors and social environmental factors. Bullying is a student who has a physical or social strength that is more appealing to another friend, has a high temperament, and a sense of empathy is low. Victims of bullying often fight against the perpetrators but some of them are subject to the command of the perpetrator and do not dare to fear. To cope with the well-programed bullying, the current countermeasures only include individual approaches by Walikelas, teacher of study field, as well as BK teachers.
\end{abstract}

Keywords: Student law awareness about the dangers of bullying

\begin{abstract}
Abstrak
Prilaku bullying di lingkungan sekolah dapat menciptakan suasana lingkungan yang kurang mendukung terhadap perkembangan diri siswa, Perilaku bullying dapat menyakiti siswa, sehing ga mereka merasa tidak diinginkan dan ditolak oleh lingkungannya. Hal ini tentunya akan membawa efek kepada berbagai kegiatan siswa disekolah. Penyebab terjadinya bullying dikarenakan oleh faktor keluarga, factor lingkungan, faktor sekolah dan faktor lingkungan pergaulan. Pelaku bullying merupakan siswa yang memiliki kekuatan baik fisik ataupun sosial yang lebih disbanding teman yang lain, memiliki tempramen tinggi, dan rasa empati yang rendah. Korban bullying yang sering melakukan perlawanan terhadap pelaku namun sebagian dari mereka tunduk kepada perintah pelaku dan tidak berani karena takut. Untuk menanggulangi bullying belum terprogram dengan baik, penanggulangan yang ada saat ini hanya meliputi pendekatan secara individu yang dilakukan oleh walikelas, guru bidang studi, maupun guru BK.
\end{abstract}

Kata kunci: Kesadaran hukum siswa tentang bahaya perbuatan Bully

\section{PENDAHULUAN}

\subsection{Analisis Situasi}

Carney \& Merrel (2001), mendefinisikan bullying sebagai sebuah perilaku yang dilakukan secara berulang-ulang untuk menyakiti orang lain. Perilaku ini dapat dilakukan dengan menyerang secara fisik atau verbal dan mengucilkan korban. Olweus
(2004) bahwa bullying merupakan tindakan negatif yang dilakukan oleh satu peserta didik atau lebih dan diulang setiap waktu.

Pelaku bullying menurut Smokowski \& Kopasz (2005) biasanya secara berlebihan bersikap agresif, destruktif,dan menikmati dominasi mereka atas anak-anak lain. Mereka juga cenderung mudah tersinggung, 
meledak-ledak, dan memiliki toleransi yang rendah terhadap frustrasi. Mereka cenderung mengalami kesulitan dalam pemrosesan informasi sosial sehingga sering menginterpretasikan secara keliru perilaku anak lain sebagai perilaku bermusuhan, bahkan ketika sebenarnya sikap permusuhan itu tidak ditunjukkan anak lain tersebut. Kebanyakan pelaku bullying memiliki sikap yang mendukung kekerasan sebagai sarana untukmenyelesaikan permasalahan mereka ereka atau sebagai sarana memperoleh apa yang mereka inginkan.

Perilaku bullying paling sering terjadi pada masa-masa sekolah menengah pertama, dikarenakan pada masa ini remaja memiliki egosentrisme yang tinggi. Adapun bentuk-bentuk bullying yang pernah terjadi antara lain seperti menyuruh push up, membentak, memelototi, memalak, mengejek dan yang paling ekstrim adalah pemukulan. Adanya ketimpangan atau ketidakseimbangan kekuatan baik fisik maupun mental menjadi penyebab terjadi perilaku bullying di sekolah.

Mentri Pemberdayaan Perempuan dan Perlindungan Anak Yohana Yambise mengatakan, menurut catatan kementrian, Provinsi Riau menempati urutan kedua tertinggi kasus kekerasan terhadap anak setelah Jawa Timur (Tempo.com. Minggu 23 Juli 2017). Sebanyak 160 kasus kekerasan terhadap anak terjadi di Kota Pekanbaru selama tahun 2017 (Bertuahpos.com Selasa 13 Maret 2018).

Beberapa faktor diyakini menjadi penyebab terjadinya perilaku bullying di sekolah, antara lain adalah faktor sosial ekonomi, perbedaan fisik yang mencolok, dan perbuatan masa lalu yang dialami peserta didik di masa lalu. Selaian hal tersebut, adanya dukungan dari kelompok teman sebaya dan iklim sekolah.

Kelompok teman sebaya memberikan pengaruh terhadap tumbuhnya perilaku bullying di sekolah. Hal tersebut yang melatarbelakangi dosen Fakultas Hukum Universitas Muhammadiyah Riau melaksanakan Pengabdian masyarakat di SMP Muhammadiyah 2 Pekanbaru untuk memberikan pemahaman kepada peserta didik tentang bullying dan upaya preventif atau pencegahan terjadinya bullying di sekolah.

\subsection{Perumusan Masalah}

Berdasarkan uraian di atas, ada beberapa permasalahan yang dapat diidentifikasikan sebagai berikut :

a. Kesadaran dan pemahaman serta pengetahuan peserta didik sangat terbatas sehingga mereka cenderung kurang peduli tanpa memikirkan akibatnya.

b. Munculnya perilaku bullying di lingkungan sekolah dapat menciptakan atmosfer lingkungan yang kurang mendukung terhadap perkembangan peserta didik, baik dalam bidang akademik maupun bidang non akademik.

\subsection{Tujuan Kegiatan}

Tujuan kegiatan Penyuluhan Hukum tentang bullying di SMP Muhammadiyah 2 Pekanbaru ini adalah:

a. Meningkatkan kesadaran dan pemahaman serta pengetahuan peserta didik tentang bullying sehingga mereka mengetahui dampak apabila mereka melakukan perbuatan tersebut.

b. Memberikan informasi tentang bullying yang dapat memberikan pengaruh buruk terhadap perkembangan peserta didik.

\subsection{Manfaat Kegiatan}

Manfaat kegiatan Penyuluhan Hukum Tentang bullying ini adalah: 
a. Diharapkan kegiatan ini bermanfaat untuk meningkatkan kesadaran, pengetahuan dan pemahaman peserta didik terhadap bullying.

b. Membantu peserta didik mengetahui cara menghindari tindakan bullying

c. Menghindarkan peserta didik dari perilaku bullying

\section{METODE PENGABDIAN}

\subsection{Sasaran dan Target Luaran}

Untuk mencapai hasil pengabdian masyarakat yang lebih optimal, maka khalayak sasaran dalam kegiatan ini adalah peserta didik SMP Muhammadiyah 2 Kota Pekanbaru. Kegiatan Sosialisasi ini diharapkan menghasilkan suatu luaran sebagai berikut :

1. Peserta Penyuluhan ini dapat mengerti dan paham tentang bullying dari aspek hukum.

2. Meningkatkan Pengetahuan peserta penyuluhan dan Memberikan kesadaran tentang pentingnya pencegahan terhadap bullyingyang dapat mempengaruhi perkembangan anak.

3. Mengembangkan Kepedulian Dosen Fakultas Hukum Universitas Muhammadiyah Riau terhadap masyarakat lingkungan di sekitarnya.

\subsection{Materi}

Materi yang disampaikan dalam kegiatan Pengabdian Kepada masyarakat oleh Program Studi Ilmu Hukum, Fakultas Hukum, Universitas Muhammadiyah Riau denga Tema "Peningkatan Kesadaran Hukum Siswa Tentang Bahaya Perbuatan Bully Di Smp Muhammadiyah 2 Pekanbaru" menyampaikan tentang apa itu bullying, bagaimana pandangan hukum tentang bullying yang disampaikan oleh tim penyuluh yang terdiri dari dosen-dosen
Fakultas Hukum Universitas Muhammadiyah Riau kepada peserta didik SMP Muhammadiyah 2 Kota Pekanbaru.

\subsection{Metode Yang Digunakan}

Dalam pelaksanaan kegiatan Pengabdian Kepada Masyarakat ini digunakan metode sebagai berikut:

a. Metode Ceramah

Dalam metode ceramah didukung oleh visualisasi, gambar dan animasi yang disusun semenarik mungkin sehingga peseta didik tertarik untuk mengikuti kegiatan sosialisasi ini yang memberikan informasi tentang bullying.

b. Metode diskusi/ tanya jawab Memberikan kesempatan kepada peserta didik untuk bertanya kepada narasumber untuk mencari pemecahan dari permasalahan yang dihadapi oleh peserta kegiatan sosialisasi.

\subsection{Indikator Keberhasilan Kegiatan Indikator untuk melihat}

keberhasilan kegiatan ini adalah:

a. Adanya peningkatan pengetahuan dan pemahaman peserta didik tentang bullying. Kegiatan ini dilakukan dengan cara mengevaluasi peserta didik dengan memberikan pertanyaan-pertanyaan yang terkait dengan materi sosialisasi yang telah dilakukan.

b. Keberhasilan peserta dalam mendapatkan pengetahuan dan pemahaman tentang bullying.

c. Tingkat penerimaan materi pelatihan dapat dilihat dari kemampuan peserta menjawab pertanyaan yang diajukan oleh tenaga penyuluh.

d. Tingkat keterlibatan dari peserta dilihat dari jumlah dan variasi 
pertanyaan yang diajukan kepada tenaga penyuluh.

e. Dari tingkat partisipasi peserta, dimana partisipasi peserta diharapkan dalam mengikuti kegiatan secara penuh dari awal sampai akhir kegiatan ini.

f. Kecocokan materi pelatihan dengan tujuan pelatihan.

\subsection{Evaluasi hasil}

Setelah kegiatan penyuluhan berakhir, diharapkan yaitu meningkatnya kesadaran dan pemahaman serta pengetahuan peserta didik tentang bullying.

\section{HASIL DAN PEMBAHASAN}

Kegiatan ini dilaksanakan sehari yaitu pada hari Rabu tanggal 12 September 2018 dari pukul $09.00 \mathrm{~s} / \mathrm{d}$ 12.00 WIB. Peserta kegiatan berjumlah 50 orang Siwa kelas VIIdan guru-guru SMP Muhammadiyah 2 Pekanbaru. lokasi kegiatan di Aula SMP Muhammadiyah 2 Pekanbaru Jl. Tengku bey II No. 28 Simpang Tiga Kota Pekanbaru.

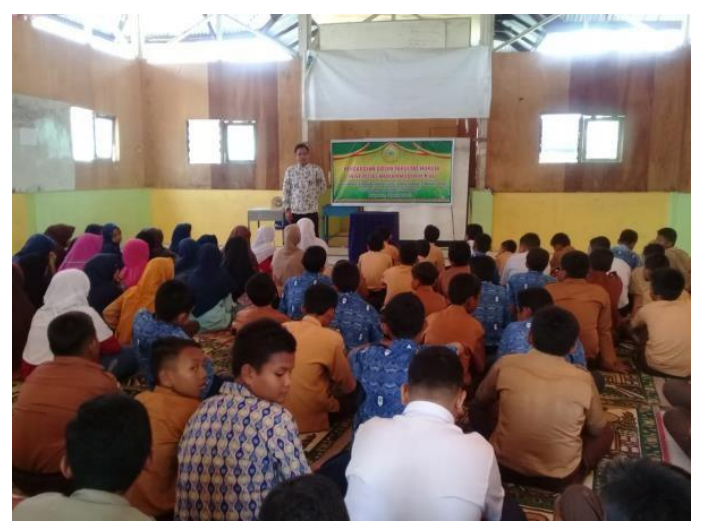

Gambar 1. Pemaparan DampakBullying

Pemateri adalah Tim dosen Fakultas Hukum Universitas Muhammadiyah Riau. Kegiatan dimulai dengan ceramah tentang bahaya Bullyingdan pentingnya kesadaran hukum siswa sebagai sarana untuk mencegah dan mengurangi terjadinya Bullying di sekolah. Dilanjutkan dengan sesi tanya jawab antara peserta dan pemateri.

Melalui kegiatan pengabdian ini diharapkan menambah pengetahuan siswa tentang bahaya perbuatan bully dan akibat hukum yang timbul apabila terjadi perbuatan negatif tersebut

Hasil kegiatan secara garis besar mencakup beberapa komponen sebagai berikut:

1. Keberhasilan target jumlah peserta penyuluhan

2. Ketercapaian tujuan penyuluhan

3. Ketercapaian target materi yang telah direncanakan

4. Kemampuan peserta dalam penguasaan materi

Secara keseluruhan kegiatan penyuluhan tentang bahaya perbuatan bully ini dapat dikatakan berhasil. Keberhasilan ini selain diukur dari keempat komponen di atas, juga dapatdilihat dari kepuasan peserta setelah mengikuti kegiatan. Antusiasme peserta mendengarkan materi dan dalam sesi tanya jawab menjadi salah satu indikator keberhasilan kegiatan.

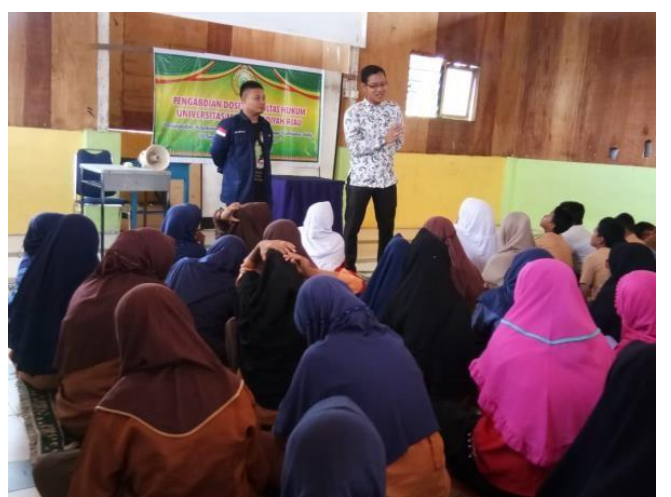

Gambar 2. Memberikan Contoh Perbuatan Bully 


\section{SIMPULAN}

a. Kegiatan bullying di sekolah merupakan satu masalah besar yang harus diatasi karena seharusnya sekolah melindungi siswanya dari tindakan kekerasan dalam bentuk apapun, dan menjadi wadah untuk pembentukan akal, moral dan karakter yang diperlukan untuk membangun masyarakat Indonesia yang sehat, berbudaya dan berteknologi tinggi. Masalah bullying di sekolah adalah tanggung jawab semua pihak yang ada di sekolah dan orang tua siswa.

b. Kegiatan Penyuluhan ini dapat diselenggarakan dengan baik dan berjalan dengan lancar sesuai dengan rencana kegiatan yang telah disusun. Kegiatan ini mendapat sambutan sangat baikterbukti dengan keaktifan peserta mengikuti penyuluhan dengan tidakmeninggalkan tempat sebelum waktu penyuluhan berakhir.

\section{UCAPAN TERIMA KASIH}

Terlaksananya pengabdian kepada masyarakat ini tidak lepas dari peran berbagai pihak, untuk itu penulis menghaturkan terima kasih kepada:

1. Rektor UMRI

2. Ketua LPPM UMRI

3. Dekan Fakultas Hukum UMRI

4. Kepala Sekolah dan Guru SMP Muhammdiyah 2 Pekanbaru

\section{DAFTAR PUSTAKA}

[1].Carney, A. G., \& Merrel, K. W. (2001). Bullying in schools: Perspectives on understanding and preventing an international problem. School Psychology International , 22, 364-379.

[2].Halimah, A., Khumas, A., \& Zainuddin, K. (2015).Persepsi pada bystander terhadap intensitas bullying pada siswa SMP. Jurnal Psikologi, 42(2), 29-140.

[3].Putri, H. N., Nauli, F. A., \& Novayelinda, R. (2015). Faktorfaktor yang berhubungan dengan perilaku bullying pada remaja. Jurnal JOM, 2(2), 1149-1159.

[4].Smokowski, P.R. \& Kopasz, K.H. (2005). Bullying in school: An overview of types, effects, family charateristics, and intervention strategies. Children \& School Journal, 27 (2): 101-109. 